\title{
PENINGKATAN KEMAMPUAN PEMECAHAN MASALAH MATEMATIKA SISWA KELAS VIII B SMP NEGERI 5 SINGARAJA MELALUI PENERAPAN MODEL PEMBELAJARAN CORE BERBANTUAN GRAPHIC ORGANIZER
}

\author{
K. D. Damayanti ${ }^{1}$, I. W. P. Astawa ${ }^{2}$, I. G. N. Y. Hartawan ${ }^{3}$ \\ Program Studi S1 Pendidikan Matematika, Jurusan Matematika, Universitas Pendidikan Ganesha, Singaraja, \\ Indonesia \\ e-mail: dwidamayanti305@gmail.com, iwp.astawa@yahoo.co.id, hartawan.math@gmail.com
}

\begin{abstract}
Abstrak
Penelitian ini bertujuan untuk mendeskripsikan : (1) peningkatan kemampuan pemecahan masalah matematika siswa kelas VIII B SMP Negeri 5 Singaraja, dan (2) tanggapan siswa kelas VIII B SMP Negeri 5 Singaraja terhadap pembelajaran matematika melalui penerapan model pembelajaran CORE berbantuan Graphic Organizer. Jenis penelitian ini adalah penelitian tindakan kelas yang dilaksanakan dalam tiga siklus. Subjek penelitian adalah siswa kelas VIII B SMP Negeri 5 Singaraja pada semester genap Tahun Ajaran 2017/2018 sebanyak 30 orang. Data kemampuan pemecahan masalah matematika siswa dikumpulkan menggunakan tes kemampuan pemecahan masalah matematika dan tanggapan siswa dikumpulkan menggunakan angket. Selanjutnya, data yang telah terkumpul dianalisis secara deskriptif. Hasil penelitian menunjukkan bahwa nilai rata-rata kemampuan pemecahan masalah matematika siswa kelas VIII B SMP Negeri 5 Singaraja meningkat dari siklus I, siklus II, hingga siklus III, yaitu 59,29 pada siklus I, 74,55 pada siklus II, dan 78,89 pada siklus III, ketuntasan belajar siswa juga mengalami peningkatan dari siklus I, siklus II, hingga siklus III, yaitu $26,67 \%$ pada siklus I, $63,33 \%$ pada siklus II, dan $80 \%$ pada siklus III. Peningkatan optimal kemampuan pemecahan masalah matematika siswa pada siklus III terjadi karena guru lebih menekankan pada: 1) pertanyaan-pertanyaan pancingan dalam mengidentifikasi permasalahan, 2) menyelesaikan rencana penyelesaian sesuai strategi yang telah disusun dengan benar, 3) pemberian bimbingan dan motivasi kepada siswa, serta 4) pemberian masalah yang dapat memberikan pengalaman belajar lebih banyak. Selain itu, tanggapan siswa terhadap penerapan model pembelajaran CORE berbantuan graphic organizer tergolong sangat positif dengan skor rata-rata tanggapan siswa 49,03.
\end{abstract}

Kata kunci: model pembelajaran CORE, graphic organizer, kemampuan pemecahan masalah matematika, tanggapan

\section{Abstract}

This study was aimed to describe: (1) the improvement of students' mathematical problem solving ability in class VIII B SMP Negeri 5 Singaraja through the application of CORE assisted graphic organizer, and (2) the response of students in class VIII B SMP Negeri 5 Singaraja toward mathematics learning through the implementation of CORE assisted graphic organizer. The type of this research was classroom action research conducted in three cycles. The subjects of research were students in class VIII B SMP Negeri 5 Singaraja on the second semester of academic year 2017/2018 consisted of 30 students. Data of students' mathematical problem solving ability were collected using mathematical problem solving ability test and students' response were collected using questionnaire. Furthermore, the collected data were analyzed descriptively. The result showed their score was slightly increased in $1^{\text {st }} \mathrm{cycle}, 2^{\text {nd }} \mathrm{cycle}$, until $3^{\text {rd }}$ cycle, such as 59,29 on the $1^{\text {st }}$ cycles, 74,55 on the $2^{\text {nd }}$ cycle, and 78,89 on the $3^{\text {rd }}$ cycle. Their achievements also reached high percentage, they were $26,67 \%$ on the $1^{\text {st }}$ cycles, $63,33 \%$ on the $2^{\text {nd }}$ cycle, and $80 \%$ on the $3^{r d}$ cycle. The ultimate score occurred on the $3^{\text {rd }}$ cycle because the teacher focused on : 1) giving stimulated questions in problem identification, 2) executing lesson plan correctly, 3) motivating the students, and 4) giving the case studies for sustainable learning. Moreover, the response of students towards CORE assisted graphic organizer was positive within score 49,03.

Keywords: CORE learning model, graphic organizer, mathematical problem solving ability, response 


\section{PENDAHULUAN}

Dalam dunia pendidikan, matematika merupakan cabang ilmu yang memiliki peran penting dalam menunjang perkembangan ilmu yang lain, seperti ilmu sains dan teknologi. Untuk mengatasi pesatnya perkembangan ilmu sains dan teknologi, diperlukan penguasaan matematika sejak dini. Pentingnya penguasaan matematika juga didukung oleh pernyataan Suherman, dkk (2003) yang memberikan beberapa alasan perlunya mempelajari matematika yaitu sebagai sarana untuk : (1) berpikir yang jelas dan logis, (2) mengasah kemampuan menalar siswa, (3) mengembangkan dan melatih pemahaman terhadap suatu masalah, (4) meningkatkan ketelitian dan kecermatan siswa. Sejalan dengan alasan tersebut, salah satu tujuan pembelajaran matematika di sekolah berdasarkan permendikbud nomor 59 tahun 2014 adalah agar siswa dapat memahami konsep matematika, yaitu menjelaskan keterkaitan antar konsep dan menggunakan konsep maupun algoritma, secara luwes, akurat, efisien, dan tepat dalam pemecahan masalah.

Kemampuan pemecahan masalah merupakan proses menerapkan pengetahuan yang sudah diperoleh sebelumnya pada situasi baru maupun berbeda (NCTM, 2000). Namun pemecahan masalah matematika ini jarang diamati secara spesifik, sehingga data yang dimiliki oleh guru hanya menggambarkan prestasi belajar siswa.

Harapan tentang pelaksanaan pembelajaran yang baik, tidak berbanding lurus dengan kenyataan yang terjadi di sekolah. Berdasarkan observasi yang dilakukan di SMP Negeri 5 Singaraja khususnya kelas VIII B, peneliti menemukan bahwa sebagian besar siswa mampu menyelesaikan soal yang serupa dengan contoh soal yang diberikan guru sebelumnya. Saat diberikan soal yang berbeda, namun masih dalam lingkup materi yang sama, banyak siswa yang mengalami kesulitan dalam memahami soal seperti apa yang diketahui dan ditanyakan dari soal tersebut. Jika siswa tidak mampu menentukan apa yang diketahui dan ditanyakan dari soal, maka siswa akan kesulitan juga dalam menentukan strategi-strategi yang tepat untuk menyelesaikan soal yang diberikan. Selain itu, siswa juga jarang membuat kesimpulan dari apa yang sudah dikerjakan, sehingga terkadang solusi yang diperoleh siswa belum menjawab dari apa yang ditanyakan pada soal.

Selain melakukan observasi, peneliti juga melakukan wawancara dengan guru matematika kelas VIII B SMP Negeri 5 Singaraja. Dari hasil wawancara dikatakan bahwa siswa kesulitan dalam merencanakan strategi yang tepat untuk menyelesaikan suatu permasalahan. Siswa cenderung langsung menyelesaikannya tanpa menuliskan rencana penyelesaian, sehingga siswa kebingungan ketika penyelesaian yang dikerjakan tidak menemukan hasil yang diharapkan. Jika dicocokkan dengan indikator ketercapaian pemecahan masalah matematika dari Polya, hasil observasi dan wawancara mengindikasikan bahwa kemampuan pemecahan masalah matematika siswa rendah.

Setelah melakukan observasi dan wawancara, untuk lebih menyakinkan peneliti bahwa di kelas VIII B SMP Negeri 5 Singaraja terjadi permasalahan, dan mengetahui atau mengukur sejauh mana kemampuan awal siswa secara tertulis, maka peneliti melakukan tes awal yang terdiri dari tiga soal. Berdasarkan data yang diperoleh dari tes kemampuan pemecahan masalah matematika diperoleh bahwa secara umum siswa masih mengalami kesulitan dalam memahami soal, terutama menentukan apa yang ditanyakan. Sehingga siswa keliru dalam mengorganisasikan ide-ide dan rencana penyelesaian. Selain itu, jawaban yang diperoleh siswa juga terkadang belum mewakili apa yang ditanyakan pada soal. Dalam hal ini, siswa tidak memeriksa kembali jawaban yang telah diperoleh serta kesimpulan yang mewakili keseluruhan jawaban terhadap apa yang ditanyakan. Hal ini akan berdampak pada rendahnya kemampuan pemecahan masalah matematika siswa. Oleh karena itu, kemampuan pemecahan masalah matematika siswa tersebut perlu mendapat perhatian dan jalan keluar yang tepat.

Untuk mengetahui lebih dalam penyebab rendahnya kemampuan pemecahan masalah matematika siswa, peneliti melakukan observasi lanjutan terhadap pelaksanaan pembelajaran di kelas VIII B SMP Negeri 5 Singaraja. Dalam observasi tersebut, ditemukan beberapa permasalahan dalam proses pembelajaran yaitu 1) Pembelajaran didominasi oleh guru, 
keadaan seperti ini kurang memberi peluang kepada siswa untuk mengeksplorasi pemahaman baru, 2) Siswa kurang tertarik mengerjakan soal yang memerlukan pemikiran kritis, 3) Siswa kurang berkontribusi saat pembelajaran dalam kelompok.

Berdasarkan informasi yang diperoleh baik dari observasi, wawancara, maupun pemberian tes awal, tampak bahwa pembelajaran matematika di kelas VIII B SMP Negeri 5 Singaraja belum mampu mengantarkan siswa untuk dapat memaksimalkan kemampuan pemecahan masalah matematika siswa. Sehingga, diperlukan model pembelajaran yang dapat memperbaiki yang bermuara pada peningkatan kemampuan pemecahan masalah matematika siswa. Hal ini sesuai dengan pendapat Partami (2012) yang menyatakan bahwa guru harus mampu membuat siswa belajar serta mengembangkan model-model pembelajaran yang sesuai dengan kondisi siswa di lapangan sehingga akan menciptakan suasana belajar yang kondusif dan interaktif.

Model pembelajaran yang dapat diterapkan untuk meningkatkan kemampuan pemecahan masalah matematika adalah model pembelajaran CORE. Menurut Calfee et al (dalam Widiyanti, 2012), model pembelajaran CORE merupakan model pembelajaran dengan metode diskusi yang didalamnya terkandung unsur mengemukakan pendapat dan tanya jawab antar siswa. Model pembelajaran CORE terdiri dari empat tahapan yaitu tahap connecting, tahap organizing, tahap reflecting, dan tahap extending. Proses pembelajaran CORE mengharapkan siswa dapat mengkontruksi pengetahuannya sendiri. Siswa menghubungkan (connecting), mengorganisasikan (organizing) pengetahuan yang diperoleh dengan pengetahuan lama kemudian memikirkan kembali konsep yang sedang dipelajari (reflecting), sehingga siswa dapat memperluas pengetahuannya selama proses pembelajaran (extending).

Untuk memperkuat penerapan model pembelajaran CORE dalam meningkatkan kemampuan pemecahan masalah matematika siswa serta pengoptimalan tiap tahap pada model pembelajaran CORE, diperlukan adanya penggunaan graphic organizer. Tiap tahap pada model pembelajaran CORE akan divisualisasikan pada graphic organizer. Jenis graphic organizer yang digunakan dalam penelitian ini adalah four corners and a diamond graphic organizer. Graphic organizer ini merupakan sebuah lembar kerja yang memiliki lima bagian penting yang masing-masing bagiannya terdapat perintah main idea, connections, brainstorming, solve, write. Menurut Zollman (2009), masing-masing bagian pada graphic organizer disesuaikan dengan indikator-indikator pemecahan masalah Polya. Dengan berbantuan graphic organizer akan lebih menunjukkan keteraturan serta kelengkapan proses berpikir siswa dari tahapan pembelajaran CORE serta membiasakan siswa menuliskan langkah-langkah dari pemecahan masalah.

Pembelajaran CORE berbantuan graphic organizer, pada tahap connecting, siswa berusaha memahami masalah dengan menemukan keterkaitan dari informasi yang terdapat dalam masalah yang diberikan. Dari keterkaitan tersebut, siswa akan mendapatkan informasi apa yang diketahui serta masalah apa yang akan dicari solusinya, sehingga siswa dapat menuliskannya pada graphic organizer bagian main idea dan connections. Kemudian tahap organizing, siswa mengorganisasikan pengetahuan yang telah dimiliki dan mengaitkannya dengan masalah yang diberikan untuk menentukan strategi pemecahan masalahnya. Strategistrategi yang mungkin dilakukan dapat ditulis pada graphic organizer bagian brainstorming. Selanjutnya siswa melaksanakan strategi yang telah ditentukan tersebut pada bagian solve dengan membangun pengetahuan baru melalui diskusi kelompok atau diskusi kelas. Tahap ketiga adalah tahap reflecting, siswa diberi kesempatan untuk memikirkan kembali solusi pemecahan masalah yang sudah diperoleh dari diskusi kelompok maupun diskusi kelas. Jika terjadi kesalahan, siswa akan menemukan kesalahannya sendiri dan belajar dari kesalahan yang dilakukan. Setelah itu, siswa menarik kesimpulan dari apa yang sudah dikerjakan. Kesimpulan tersebut dapat dituliskan pada graphic organizer bagian write. Tahap terakhir dari model pembelajaran CORE adalah extending. Pada tahap ini siswa mengaplikasikan pengetahuan yang terbangun pada tahap-tahap sebelumnya ke dalam sistuasi baru atau konteks yang berbeda dari masalah sebelumnya. Siswa akan lebih berkesempatan untuk melatih dan mengembangkan kemampuan pemecahan masalah matematikanya. 
Hal ini juga di dukung oleh beberapa hasil penelitian yang relevan salah satu diantaranya: 1) Hasil penelitian Widiantari, dkk (2016) yang memperoleh kesimpulan bahwa siswa yang dibelajarkan dengan menggunakan model pembelajaran CORE memperoleh hasil kemampuan pemecahan masalah matematika lebih tinggi dari siswa yang dibelajarkan dengan cara konvensional, 2) Hasil penelitian Putra, dkk (2015) memperoleh kesimpulan bahwa siswa yang dibelajarkan dengan menggunakan model pembelajaran CORE memperoleh hasil kemampuan komunikasi matematis lebih tinggi dari siswa yang dibelajarkan dengan cara konvensional, 3) Hasil penelitian yang dilakukan oleh Limond (2012) terkait penggunaan graphic organizer. Hasil penelitian terebut terbukti dapat meningkatkan kemampuan pemecahan masalah matematika siswa, karena tiap bagian pada graphic organizer mendukung indikator kemampuan pemecahan masalah matematika.

Adapun tujuan dari penelitian ini adalah untuk mengetahui (1) peningkatan kemampuan pemecahan masalah matematika siswa kelas VIII B SMP Negeri 5 Singaraja melalui penerapan model pembelajaran CORE berbantuan graphic organizer dan (2) tanggapan siswa kelas VIII B SMP Negeri 5 Singaraja terhadap penerapan model pembelajaran CORE berbantuan graphic organizer.

\section{METODE}

Penelitian yang dilaksanakan adalah penelitian tindakan kelas (classroom action research) yang secara umum bertujuan meningkatkan dan memperbaiki kualitas, proses, dan hasil pembelajaran matematika di kelas. Penelitian ini dilaksanakan dalam tiga siklus. Setiap siklus terdiri dari empat tahap yaitu perencanaan tindakan, pelaksanaan tindakan, observasi dan evaluasi serta refleksi (Komaidi, 2011). Kemampuan pemecahan masalah matematika diukur melalui tes uraian yang diberikan pada setiap akhir siklus dan tanggapan siswa dikumpulkan menggunakan angket yang diberikan pada akhir siklus III. Data kemampuan pemecahan masalah matematika dan tanggapan siswa yang sudah terkumpul kemudian dianalisis menggunakan teknik analisis deskriptif.

\section{HASIL DAN PEMBAHASAN}

\section{Hasil Penelitian Refleksi Awal}

Pada tahap refleksi awal, siswa kelas VIII B SMP Negeri 5 Singaraja diberikan tes awal kemampuan pemecahan masalah berbentuk soal uraian. Rata-rata kemampuan pemecahan masalah matematika pada adalah 39,80 dan ketuntasan belajar secara klasikal adalah $10 \%$. Pada tahap refleksi awal, diperoleh gambaran awal mengenai proses pembelajaran matematika yang dialami oleh siswa Kelas VIII B SMP Negeri 5 Singaraja. Setelah itu, siswa Kelas VIII B SMP Negeri 5 Singaraja diberikan tes awal untuk mengetahui kemampuan pemecahan masalah matematika siswa sebelum diberikan tindakan. Berdasarkan hasil tes awal diperoleh bahwa kemampuan pemecahan masalah matematika siswa sebelum diberikan tindakan masih belum mencapai KKM yang ditetapkan atau masih tergolong rendah.

Sebelum melaksanakan kegiatan pembelajaran pada siklus I menggunakan penerapan model pembelajaran CORE berbantuan graphic organizer, peneliti mengadakan kegiatan pra siklus yang dilakukan oleh guru pengajar di kelas VIII B SMP Negeri 5 Singaraja. Hal ini dilakukan agar terjadi penyamaan persepsi antara peneliti dengan guru pengajar. Sebelum pra siklus dilakukan, peneliti memberikan graphic organizer kepada guru pengajar.

\section{Hasil Penelitian Siklus I}

Pada akhir siklus I siswa diberikan tes yang terdiri dari tiga soal uraian. Dari analisis data tersebut diperoleh rata-rata nilai kemampuan pemecahan masalah matematika siswa adalah 59,29 dan ketuntasan belajar siswa secara klasikal adalah 26,67\%, yaitu hanya 8 siswa dari 30 siswa yang mampu mencapai KKM. Adapun sebaran data mengenai kemampuan pemecahan masalah matematika siswa dapat diperhatikan pada Gambar 1.1 berikut. 


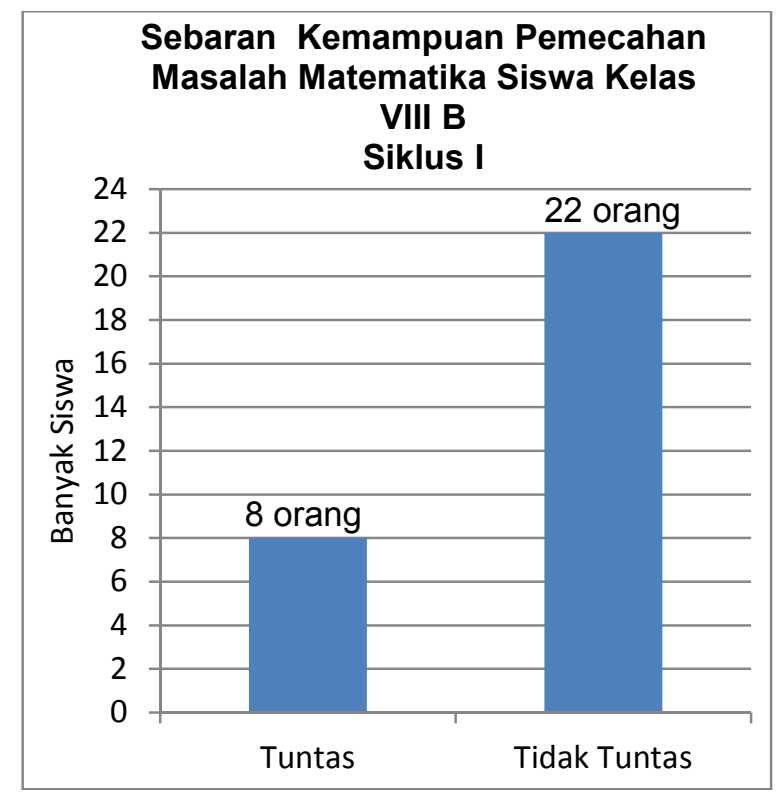

Gambar 1.1 Sebaran Kemampuan Pemecahan Masalah Matematika Siswa Kelas VIII B pada Siklus I

Dapat disimpulkan bahwa rata-rata nilai kemampuan pemecahan masalah matematika yang dimiliki siswa kelas VIII B SMP Negeri 5 Singaraja pada siklus I belum memenuhi kriteria ketuntasan minimal yang telah ditetapkan. Selain itu, ketuntasan belajar siswa secara klasikal juga belum memenuhi kriteria yang telah ditetapkan. Walaupun secara klasikal belum memenuhi kriteria ketuntasan minimal yang telah ditetapkan, tetapi rata-rata nilai kemampuan pemecahan masalah matematika yang dimiliki siswa dan ketuntasan belajar siswa sudah mengalami peningkatan dari refleksi awal ke siklus I.

\section{Hasil Penelitian Siklus II}

Pada akhir siklus II siswa diberikan tes yang terdiri dari empat soal uraian. Dari analisis data tersebut diperoleh rata-rata nilai kemampuan pemecahan masalah matematika siswa adalah 74,55 dan ketuntasan belajar siswa secara klasikal adalah 63,33\%, yaitu hanya 19 siswa dari 30 siswa yang mampu mencapai KKM. Adapun sebaran data mengenai kemampuan pemecahan masalah matematika siswa dapat diperhatikan pada Gambar 1.2 berikut. 


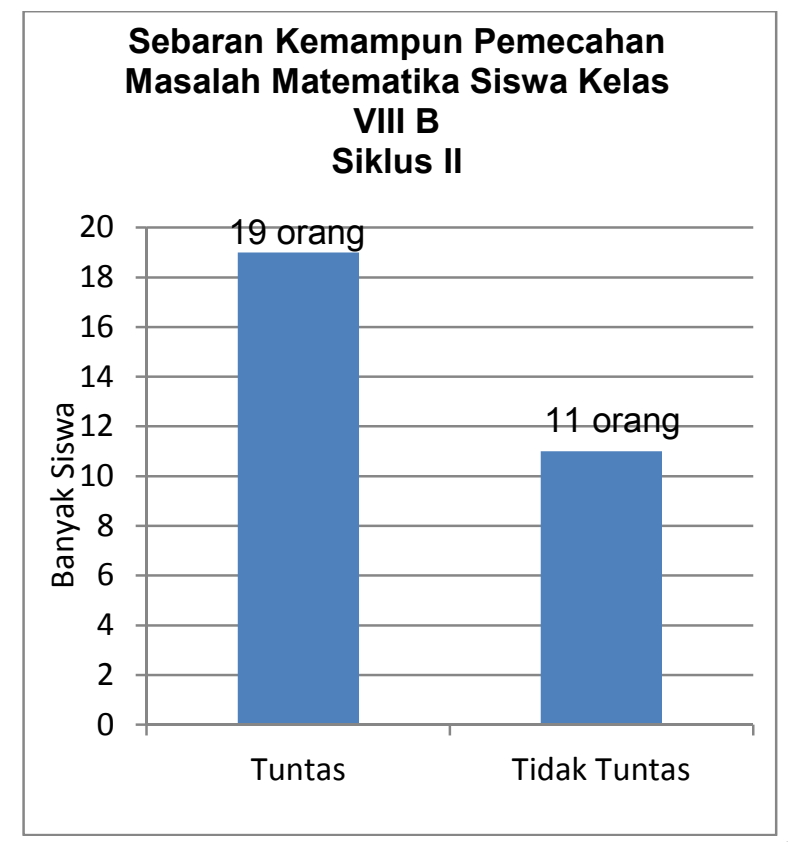

Gambar 1.2 Sebaran Kemampuan Pemecahan Masalah Matematika Siswa Kelas Kelas VIII B pada Siklus II

Berdasarkan analisis data di atas, dapat disimpulkan bahwa rata-rata nilai kemampuan pemecahan masalah matematika yang dimiliki siswa kelas VIII B SMP Negeri 5 Singaraja pada siklus II belum memenuhi kriteria ketuntasan minimal yang telah ditetapkan. Selain itu, ketuntasan belajar siswa secara klasikal belum memenuhi kriteria yang telah ditetapkan yaitu $75 \%$. Walaupun ketuntasan belajar siswa secara klasikal belum memenuhi kriteria yang telah ditetapkan, tetapi rata-rata nilai kemampuan pemecahan masalah matematika yang dimiliki siswa dan ketuntasan belajar siswa itu sendiri sudah mengalami peningkatan dari siklus I ke siklus II.

\section{Hasil Penelitian Siklus III}

Pada akhir siklus III siswa diberikan tes yang terdiri dari tiga soal uraian. Dari analisis data tersebut diperoleh rata-rata nilai kemampuan pemecahan masalah matematika siswa adalah 78,89 dan ketuntasan belajar siswa secara klasikal adalah $80 \%$, yaitu 24 siswa dari 30 siswa yang mampu mencapai KKM. Adapun sebaran data mengenai kemampuan pemecahan masalah matematika siswa dapat diperhatikan pada Gambar 1.3 berikut.

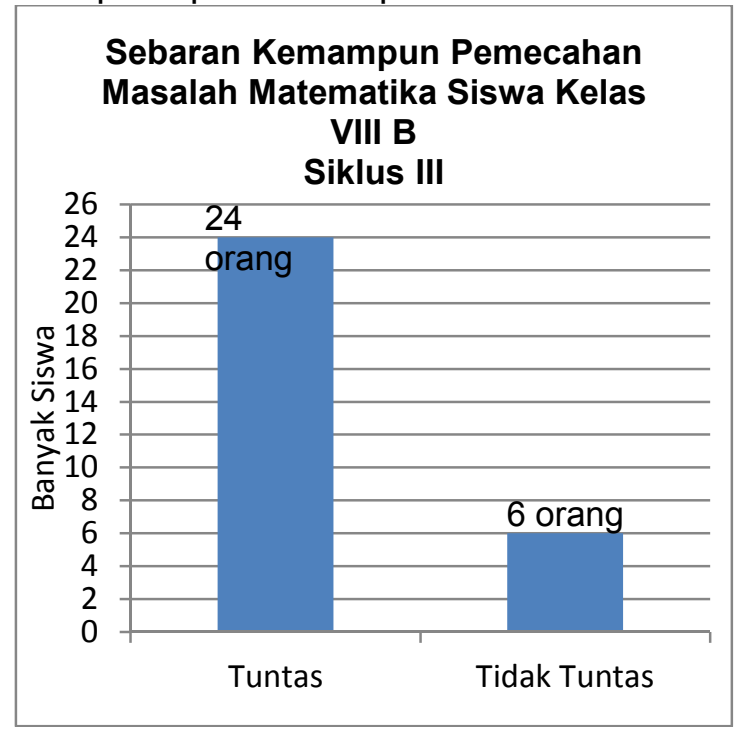

Jurnal Pendidikan dan Pembelajaran Matematika Indonesia | 54 


\section{Gambar 1.3 Sebaran Kemampuan Pemecahan Masalah Matematika Siswa Kelas VIII B pada Siklus III}

Berdasarkan analisis data di atas, dapat disimpulkan bahwa rata-rata nilai kemampuan pemecahan masalah matematika yang dimiliki siswa kelas VIII B SMP Negeri 5 Singaraja pada siklus III sudah memenuhi kriteria ketuntasan minimal serta ketuntasan belajar siswa secara klasikal sudah memenuhi kriteria yang telah ditetapkan serta mengalami peningkatan dari siklus II.

\section{Peningkatan Kemampuan Pemecahan Masalah Matematika Siswa}

Peningkatan rata-rata nilai kemampuan pemecahan masalah matematika siswa ditunjukkan dengan grafik seperti Gambar 1.4 berikut ini.

\section{Gambar 1.4 Grafik Peningkatan Rata-Rata Nilai Kemampuan Pemecahan Masalah} Matematika Siswa

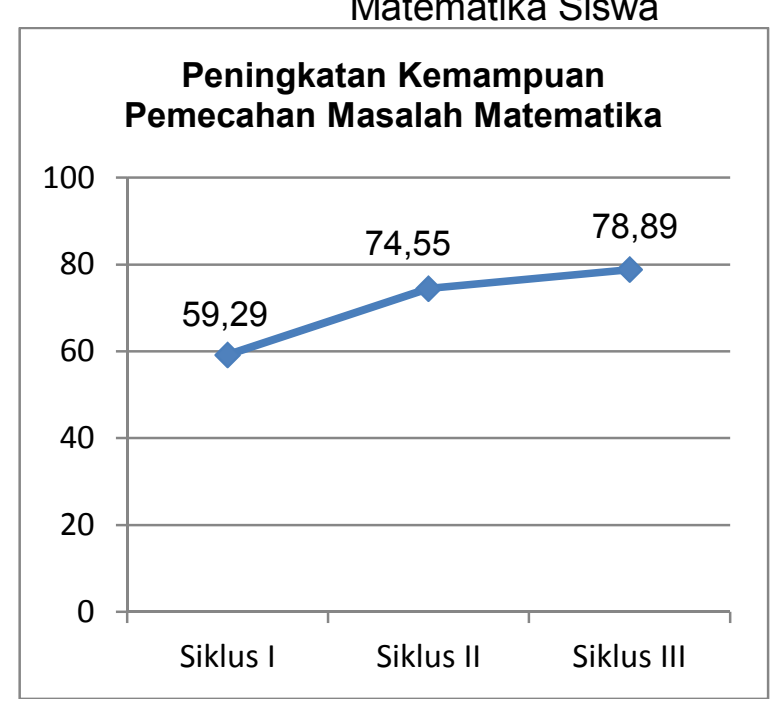

Peningkatan rata-rata nilai kemampuan pemecahan masalah matematika yang dimiliki siswa dari refleksi awal ke siklus I sebesar 19,49 dari rata-rata nilai kemampuan pemecahan masalah matematika yang dimiliki siswa pada refleksi awal, peningkatan nilai kemampuan pemecahan masalah matematika yang dimiliki siswa dari refleksi awal ke siklus II adalah 34,75 dari rata-rata nilai kemampuan pemecahan masalah matematika yang dimiliki siswa pada refleksi awal, dan peningkatan kemampuan pemecahan masalah matematika yang dimiliki siswa dari refleksi awal ke siklus III sebesar 39,09 dari rata-rata nilai kemampuan pemecahan masalah matematika pada refleksi awal.

Peningkatan ketuntasan belajar siswa ditunjukkan dengan grafik seperti Gambar 1.5 berikut ini.

Gambar 1.5 Grafik Peningkatan Ketuntasan Belajar Siswa 


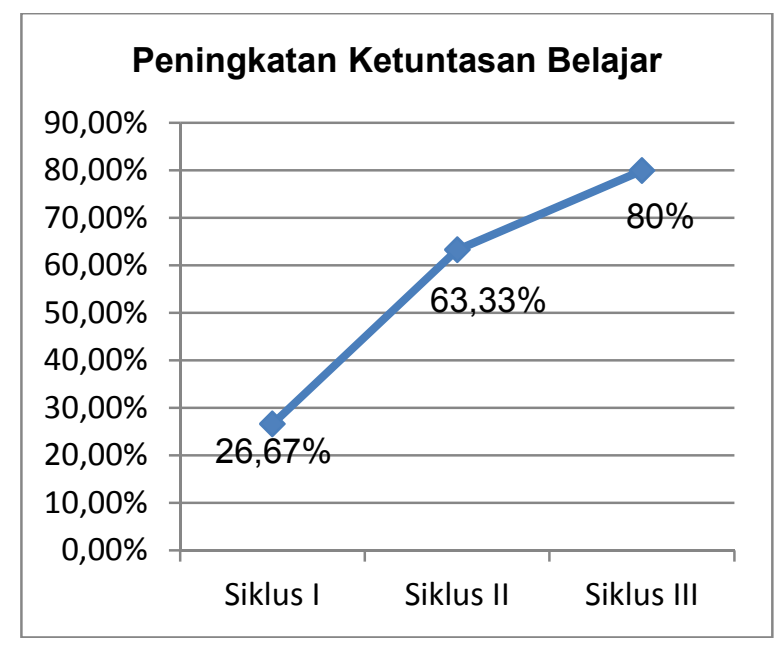

\section{Tanggapan Siswa}

Pada akhir pertemuan siklus III, siswa juga diberikan angket untuk mengetahui tanggapan siswa terhadap penerapan model pembelajaran CORE berbantuan graphic organizer. Data mengenai tanggapan siswa terhadap penerapan model pembelajaran CORE berbantuan graphic organizer dikumpulkan pada akhir siklus III dengan menggunakan angket tanggapan siswa yang terdiri dari 15 butir pernyataan. Berdasarkan data tersebut diperoleh rata-rata skor tanggapan siswa terhadap penerapan model pembelajaran CORE berbantuan graphic organizer selama proses pembelajaran adalah 49,03.

Sebaran data siswa yang memberikan respon sangat positif, positif, cukup, kurang positif dan sangat kurang positif disajikan pada Gambar 1.6 berikut.

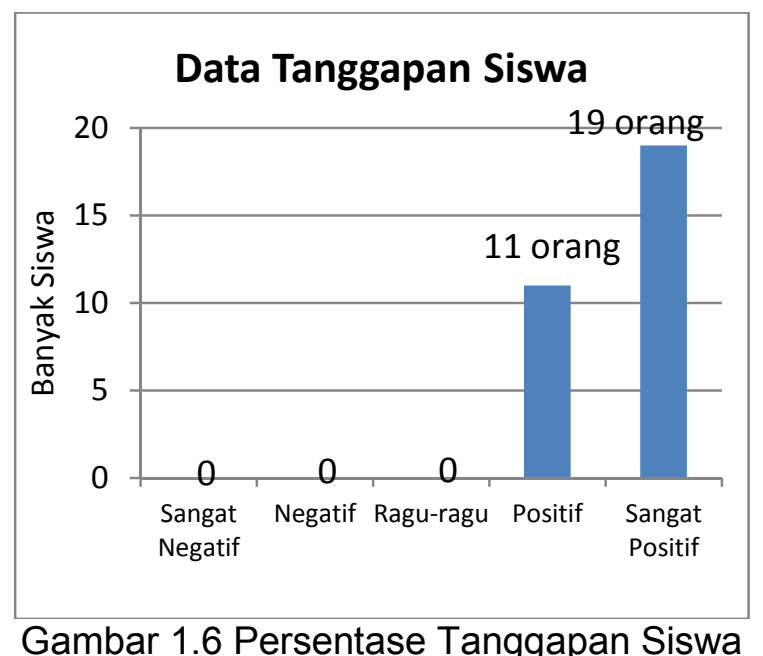

Berdasarkan rata-rata skor tanggapan siswa terhadap penerapan model pembelajaran CORE berbantuan graphic organizer selama proses pembelajaran, dapat disimpulkan bahwa pembelajaran melalui penerapan model pembelajaran CORE berbantuan graphic organizer mendapatkan tanggapan yang sangat positif dari siswa sesuai dengan kriteria penggolongan tanggapan siswa, sehingga tanggapan siswa terhadap penerapan model pembelajaran CORE berbantuan graphic organizer selama proses pembelajaran sudah memenuhi kriteria indikator keberhasilan. 


\section{PEMBAHASAN}

Tercapainya peningkatan kemampuan pemecahan masalah matematika yang dimiliki siswa secara optimal terjadi pada siklus III, hal ini dapat dilihat dari adanya peningkatan hasil tindakan yang dilakukan untuk menyelesaikan permasalahan yang ditemui pada observasi dan setelah adanya pelaksanaan tindakan pada siklus I hingga siklus III sudah mengalami perubahan dan peningkatan dari siklus ke siklus. Adapun hal-hal yang menyebabkan terjadinya peningkatan kemampuan pemecahan masalah matematika yang dimiliki siswa adalah sebagai berikut.

Pertama, pada proses pembelajaran guru lebih menekankan pada menghubungkan informasi-informasi yang ada dengan pengetahuan yang sudah dimiliki siswa melalui pertanyaan-pertanyaan pancingan dalam mengidentifikasi permasalahan. Melalui tindakan ini, dapat mengurangi kesulitan siswa dalam menghubungkan permasalahan dengan pengetahuan yang sudah dimiliki siswa untuk mengidentifikasi permasalahan yang ada pada LKS. Tindakan ini sudah dilakukan pada siklus II dan siklus III. Untuk membiasakan siswa mengidentifikasi masalah terlebih dahulu, ditekankan penggunakan graphic organizer pada bagian main idea dan connections, sehingga siswa akan terbiasa mengidentifikasi masalah dengan menuliskan yang diketahui dan ditanyakan pada soal.

Kedua, menekankan pada siswa untuk menuliskan rencana penyelesaian pada graphic organizer. Pada siklus II, ketidaklengkapan siswa menyelesaikan rencana penyelesaian yang telah disusun, mengakibatkan apa yang sudah dikerjakan siswa belum mampu menjawab apa yang ditanyakan pada soal. Untuk mengurangi hal tersebut, guru mengoptimalkan penggunaan graphic organizer terutama pada bagian brainstorming dan solve. Pada siklus III, terlihat dari jawaban siswa bahwa langkah-langkah yang sudah dikerjakan sesuai dengan rencana yang telah disusun. Sehingga kemungkinan besar jawaban siswa benar.

Ketiga, membimbing dan memotivasi siswa, serta memberikan kesempatan dan penekanan kepada siswa agar aktif menjawab, menyampaikan hasil diskusi, serta memberikan tanggapan atas ide-ide yang disampaikan oleh temannya. Hal ini membantu guru mengetahui ide-ide siswa dalam mengerjakan LKS. Sehingga guru bisa menengahi apabila ada kekeliruan dalam pengerjaan LKS. Selain itu, untuk menghindari dominasi satu atau dua orang dalam kelompok, guru melakukan sistem acak dalam menunjuk siswa yang mempresentasikan hasil diskusi di depan kelas. Tindakan ini efisien dilakukan karena terlihat perubahan dari siklus I hingga siklus III dalam hal keseriusan belajar siswa. Sesuai dengan yang disampaikan oleh Sardiman (2011) bahwa motivasi belajar dapat dijadikan sebagai keseluruhan daya penggerak dalam diri siswa yang menimbulkan kegiatan belajar, yang menjamin kelangsungan dari kegiatan belajar dan memberikan arah pada kegiatan belajar, sehingga tujuan yang dikehendaki oleh subjek belajar itu dapat tercapai.

Keempat, guru memberikan latihan soal yang dapat memperluas pemahaman siswa terkait materi yang telah dipelajari. Pada latihan soal ini, guru tetap menggunakan graphic organizer agar siswa terbiasa bekerja secara sistematis, sehingga diperoleh hasil akhir yang benar. Setelah memperoleh hasil, guru kembali mengingatkan siswa untuk menyimpulkan dari apa yang sudah dikerjakan siswa. Karena dari proses menyimpulkan, siswa akan kembali mengecek pekerjaannya, apakah hasil yang diperoleh sudah menjawab pertanyaan dari soal yang diberikan. Sesuai dengan yang disampaikan oleh Suteja (2014), penulisan kesimpulan akan memacu siswa melihat kembali masalah dan apa yang ditanyakan, sehingga membantu dalam mendeteksi kesalahan pengerjaan..

Melalui beberapa upaya perbaikan pelaksanaan tindakan sesuai hasil refleksi siklus I, siklus II, dan siklus III ternyata memberikan peningkatan dari proses pembelajaran yang berlangsung. Adapun usaha yang dilakukan selama pemberian tindakan, diantaranya membimbing secara intensif untuk membantu siswa dalam pengerjaan LKS ataupun soal-soal latihan dan memotivasi siswa sehingga lebih bersemangat dalam mempelajari materi yang diberikan serta secara tidak langsung meningkatkan keaktifan siswa. Kemudian melakukan pendekatan kepada tiap kelompok saat diskusi untuk membiasakan kelompok terbuka dengan 
masalah yang dihadapi ternyata memberikan pengaruh yang baik terhadap keefisienan jalannya diskusi. Selain itu, interaksi dan tanggapan siswa terhadap pertanyaan-pertanyaan yang diberikan oleh guru juga meningkat dalam hal kualiatas argumen yang diberikan.

Secara umum, hasil penelitian yang diperoleh sejalan dengan penelitian yang telah dilakukan oleh Widiantari, dkk (2016) yang memperoleh kesimpulan bahwa siswa yang dibelajarkan dengan menggunakan model pembelajaran CORE memperoleh hasil kemampuan pemecahann masalah matematika lebih tinggi dari siswa yang dibelajarkan dengan cara konvensional. Hal tersebut juga sesuai dengan penelitian yang dilakukan oleh Putra, dkk (2015) juga memperoleh kesimpulan bahwa siswa yang dibelajarkan dengan menggunakan model pembelajaran CORE memperoleh hasil kemampuan komunikasi matematis lebih tinggi dari siswa yang dibelajarkan dengan cara konvensional. Salah satu indikator kemampuan komunikasi matematis yaitu mampu mengekspresikan ide-ide matematis melalui tulisan dan menggambarkannya secara visual. Dengan kemampuan tersebut, dapat membantu siswa mempermudah memahami permasalahan serta menyususn rencana penyelesaian yang relevan. Dalam hal ini juga berpengaruh terhadap kemampuan pemecahan masalah matematika siswa. Penelitian yang dilakukan oleh Limond (2012) terkait penggunaan graphic organizer. Hasil penelitian terebut terbukti dapat meningkatkan kemampuan pemecahan masalah matematika siswa, karena tiap bagian pada graphic organizer mendukung indikator kemampuan pemecahan masalah matematika.

Selain terjadi peningkatan kemampuan pemecahan masalah matematika yang dimiliki siswa, penerapan model pembelajaran CORE berbantuan graphic organizer dalam pembelajaran matematika juga mendapatkan respon sangat positif dari siswa. Dengan demikian, hasil penelitian ini telah memenuhi semua indikator keberhasilan yang telah ditetapkan. Jadi dapat disimpulkan penelitian sudah berhasil.

\section{SIMPULAN DAN SARAN Simpulan}

Berdasarkan hasil analisis data dan pembahasan hasil penelitian, diperoleh simpulan sebagai berikut.

Penerapan model pembelajaran CORE berbantuan graphic organizer mampu meningkatkan kemampuan pemecahan masalah matematika siswa kelas VIII B SMP Negeri 5 Singaraja. Hal ini dilihat dari rata-rata nilai tes kemampuan pemecahan masalah matematika siswa meningkat pada setiap siklus. Sebelum diberikan tindakan, kemampuan pemecahan masalah amtematika pada tes awal masih rendah. Pada siklus I dan II, rata-rata nilai kemampuan pemecahan masalah siswa adalah 59,29 dan 74,55, dengan kata lain belum mencapai KKM. Pada siklus III rata-rata nilai kemampuan pemecahan masalah siswa menjadi 78,89 dan sudah mencapai KKM. Persentase ketuntasan belajar klasikal juga meningkat pada setiap siklus dan mencapai $75 \%$ pada siklus III.

Terjadinya peningkatan kemampuan pemecahan masalah matematika siswa disebabkan oleh beberapa hal berikut. 1) Mengarahkan siswa melalui pertanyaan-pertanyaan pancingan untuk mempermudah dalam menghubungkan informasi-informasi yang ada dengan konsep-konsep lama. 2) Menekankan kepada siswa untuk melaksanakan penyelesaian permasalahan sesuai dengan strategi yang telah disusun dengan benar. 3) Pemberian bimbingan dan motivasi kepada siswa agar aktif menjawab, menyampaikan hasil diskusi, serta memberikan tanggapan. Selain itu, melakukan sistem acak untuk menghindari dominasi satu atau dua orang dalam kelompok. 4) Memberikan latihan soal yang dapat memperluas pemahaman siswa terkait materi yang telah dipelajari.

Tanggapan siswa kelas VIII B SMP Negeri 5 Singaraja terhadap penerapan model pembelajaran CORE berbantuan graphic organizer tergolong positif dengan rata-rata skor 49,03. Hasil tanggapan siswa menunjukkan bahwa dari 30 siswa, 19 siswa memberikan tanggapan sangat positif dan 11 siswa memberikan tanggapan positif. Hal ini menunjukkan 
bahwa model pembelajaran CORE berbantuan graphic organizer efektif dalam meningkatkan proses pembelajaran.

\section{Saran}

Berdasarkan hasil penelitian yang diperoleh, adapun saran-saran yang penulis dapat sampaikan yaitu sebagai berikut.

Model pembelajaran CORE berbantuan graphic organizer dapat dipertimbangkan untuk diterapkan sehingga pembelajaran matematika berlangsung secara lebih bermakna dan dapat meningkatkan kemampuan pemecahan masalah matematika siswa

Bagi pembaca yang ingin melaksanakan penelitian lebih lanjut mengenai model pembelajaran CORE berbantuan graphic organizer diharapkan agar memperhatikan permasalahan yang dialami selama pelaksanaan penelitian ini untuk perbaikan pelaksanaan penelitian lanjutan. Model pembelajaran CORE berbantuan graphic organizer dapat pula dipertimbangkan untuk meningkatkan kemampuan matematis lainnya.

\section{DAFTAR PUSTAKA}

Komaidi, D., dan Wahyu Wijayanti. 2011. Panduan Lengkap PTK (Penelitian Tindakan Kelas). Yogyakarta : Sabda Media.

Limond, Linda. 2012. A Reading Strategy Approach to Mathematicah Problem Solving. Illinois Reading Council Journal Vol. 40 No. 02: 31-42. Tersedia pada https://mathandliteracywebsite.weebly.com/uploads/1/9/0/4/19046679/article 1.pdf. Diakses tanggal 25 November 2017.

NCTM. 2000. Mathematics Assesment a Practical Handbook for Grades 6-8. United States of America : NCTM.

Partami, D. C. 2012. Implementasi Strategi pembelajaran REACT (Relating, Experiencing, Applying, Cooperating, and Transferring) untuk Meningkatkan Motivasi dan Prestasi Belajar Matematika Siswa Kelas VIII G SMP Negeri 5 Singaraja Tahun Ajaran 2011/2012. Skripsi (tidak diterbitkan) Fakultas Matematika dan Ilmu Pengetahuan Alam.

Putra, dkk. 2015. "Pengaruh Model Pembelajaran CORE (Connecting, Organizing, Reflecting, Extending) Terhadap Kemampuan Komunikasi Matematis Siswa Kelas X SMA Negeri 1 Bebandem. Jurusan Pendidikan Matematika. Vol. 3, No. 1.

Suherman, E., dkk. 2003. Model Pemelajaran Matematika Kontemporer. Bandung: JICA UPI

Suteja, I G.L. 2014. Implementasi Model Pembelajaran Pemecahan Masalah dengan Metode Means-Ends Analysis (MEA) untuk Meningkatkan Kemampuan Pemecahan Masalah dan Kepercayaan Diri Siswa Kelas VIII B1 SMP Negeri 4 Singaraja. Skripsi (tidak diterbitkan).Singaraja: Universitas Pendidikan Ganesha.

Widiantari, dkk. 2016. "Pengaruh Penerapan Model Pembelajaran CORE (Connecting, Organizing, Reflecting, Extending) dalam Pembelajaran Matematika Terhadap Kemampuan Pemecahan Masalah Matematika Siswa Kelas X SMA Laboratorium Undiksha”. Jurusan Pendidikan Matematika. Vol 5, No 2..

Widiyanti, N. 2012. Penerapan Model CORE (Connecting, Organizing, Reflecting, Extending) Untuk Meningkatkan Aktivitas dan Hasil Belajar Siswa Kelas VIII B di SMP Negeri 1 Sukasada. Skripsi (Tidak Diterbitkan). Singaraja : Universitas Pendidikan Ganesha. 
Zollman, Alan. 2009. Students Use Graphic Organizers to Improve Mathematical Problem Solving Communications. Middle School Journal, Vol. 41, No. 2: 4-12. Tersedia pada http://files.eric.ed.gov/fulltext/EJ868542.pdf. Diakses tanggal 25 November 2017. 